\title{
The Effects of Cyclosporine and Tacrolimus on Gingiva and Alveolar Bone of Rats
}

\author{
Ural Karaduman ${ }^{1}$, Burcu Karaduman² ${ }^{\circledR}$, Ilhami Celik ${ }^{3}$, Mihtikar Gursel ${ }^{4}$ \\ ${ }^{1}$ Private practice, Osmaniye, Turkey \\ ${ }^{2}$ Biruni University, Faculty of Dentistry, Department of Periodontology, Istanbul, Turkey \\ ${ }^{3}$ Selcuk University Faculty of Veterinary Medicine, Department of Histology and Embryology, Konya, Turkey \\ ${ }^{4}$ Bezmialem University, Faculty of Dentistry, Department of Periodontology, Istanbul, Turkey \\ Correspondence Author: Mihtikar Gursel \\ E-mail: mgursel@bezmialem.edu.tr \\ Received: $04.12 .2020 \quad$ Accepted: 25.03 .2021
}

\begin{abstract}
Objective: Cyclosporine A ( $\mathrm{CsA}$ ) and tacrolimus (Tac) are immunosuppressive drugs which is frequently used in organ transplantation. CsA can cause various side effects including gingival overgrowth $(\mathrm{GO})$ and osteopenia. Tac has similar side effects to CsA but with different incidences. The aim of the present study was to evaluate and compare the effects of CSA and Tac on GO and alveolar bone resorption in rats.

Methods: Sixty mature male rats were randomly and equally allocated into six groups, as follows: Control-I, Control-II, CSA-I, CsA-II, Tac-I and Tac-II. The Control-I and Control-II groups received, subcutaneously, $1 \mathrm{ml} / \mathrm{kg} 0.9 \% \mathrm{NaCl}$, while the CsA-I and CsA-II groups received $10 \mathrm{mg} / \mathrm{kg}$ CsA daily, and the Tac-I and Tac-II groups $1.5 \mathrm{mg} / \mathrm{kg}$ Tac daily. The Control-I, CSA-I and Tac-I groups were sacrificed on the $16^{\text {th }}$ day and other groups on the $31^{\text {st }}$ day. Histological and histomorphometric analysis of the buccal gingiva and tartrate-resistant acid phosphatase (TRAP) enzyme histochemistry of the alveolar bone were performed in the right mandibular segment of each animal.
\end{abstract}

Results: GO was significantly greater in the groups administered CsA compared to the other groups $(P<0.05)$. The gingival parameters in the Tac groups were quite similar to those in the control group $(P>0.05)$. CsA caused a significant increase in TRAP positivity $(P<0.05)$, while Tac had no significant effect on TRAP $(\mathrm{P}>0.05)$.

Conclusion: Our results showed that Tac does not seem to cause GO and alveolar bone resorption. However, the deleterious side effects of Tac on the gingival tissues of rats may be time-related.

Keywords: Bone Resorption, Cyclosporine A, Gingival Overgrowth, Tacrolimus, Tartrate-Resistant Acid Phosphatase.

\section{INTRODUCTION}

Gingival overgrowth (GO) has many etiologies, but has often been associated with the systemic administration of certain medications, particularly anticonvulsants, calcium channel blockers, and immunosuppressants (1). Immunosuppressive drugs cause selective inhibition or suppression on various components of the immune system. Cyclosporine A (CsA), which is an immunosuppressive agent, is a T lymphocyte suppressor used to restrain rejection in organ transplants. Although it is a unique selective immunosuppressant drug, CsA has a number of side effects, such as nephrotoxicity, neurotoxicity, diabetes, osteopenia, and GO (2). As a result of the difficulties associated with the emergence of CsA side effects, tacrolimus (Tac) was introduced as a less toxic but more potent calcineurin inhibitor (3). Both CsA and Tac show their immunosuppressive activity by inhibiting the calcineurin pathway. CsA is still considered to be the most effective immunosuppressive drug currently in use (4).
Tac has been shown to have similar side effects to CsA but with different incidences (2). Both drugs were found to have similar incidences of nephrotoxicity (5). Tac has a less acute rejection rate and better allograft survival rate (5). However, it is more associated with diabetes mellitus and neurotoxicity after transplantation (5). On the other hand, complications such as hyperlipidemia, hypertension and hirsutism with Tac are less common (5). Similarly, although there are many studies showing various degrees of GO due to CsA use (6), it has been suggested that the use of Tac does not cause GO (7), or causes less GO than CsA, and is less severe when it causes GO $(8,9)$. There are also studies showing that GO spontaneously decreases with the replacement of CsA with Tac in patients with GO caused by CSA (10).

Osteopenia is a significant complication of organ transplantation. Conflicting evidence has been presented on the interference of calcineurin inhibitors with the bone metabolism. While some studies have shown that Tac causes 
an increase in alveolar bone formation by decreasing the number of osteoclasts (11), in contrast, it has also been reported that by increasing the number of osteoclasts, Tac increases bone resorption but does not affect bone formation (12). CsA, on the other hand, has been shown to increase bone formation and bone resorption, causing highturnover bone loss (12). Kanda et al. also found bone mineral density after CsA to be significantly lower than after Tac (12). It was reported that there was an increase in bone volume and a decrease in the number of osteoclasts in rats following the replacement of CsA with Tac (13). Similarly, it has been demonstrated in experimental periodontitis that Tac reduces the severity of periodontitis (14).

The most effective treatment for the patients with druginduced gingival overgrowth is to replace the drug with another medication that has fewer side effects. Treatment plan is primarily performed in consultation with the patient's physician by considering the systemic condition of the patient. In recent years, Tac has been recognized as a noteworthy alternative to CSA in patients with gingival overgrowth. However, the studies suggesting that both drugs have possible effects on bone metabolism raise concerns about the negative effects of the drug choice or replacement on alveolar bone.

Tartrate-resistant acid phosphatase (TRAP) has been established as a reliable, specific and sensitive histochemical marker of bone resorption in that it is an enzyme synthesized and secreted by bone-resorbing cells, osteoclasts $(12,13,15)$. Osteoclasts can be stained for TRAP as a means of assessing the number of osteoclasts in addition to their activity. TRAP levels have been shown to be elevated in the serum of patients with bone diseases and the amount of secreted TRAP significantly correlated with the number of osteoclasts $(12,13,15)$.

The effects and mechanisms of action of CsA and Tac on bone metabolism are still unclear. Knowing the possible effects of these calcineurin inhibitors on periodontal tissues may improve the effectiveness of periodontal treatment and the quality of life of patients using these drugs. Therefore, the purpose of the present study focused on evaluating and comparing the effects of CSA and Tac on GO and bone metabolism. In this study, standardized histomorphometric variables were used together with TRAP activity as a histochemical marker in histological sections.

\section{METHODS}

\subsection{Animals and Experimental Design}

Sixty mature (4 months old), male Sprague-Dawley rats weighing between 195-205 g were used in this study. The animals were obtained from the Experimental Medicine Research and Application Centre of Selcuk University. The preparation of the animals was performed by their spending a habituation period of one week in the same center prior to the experiment. The animals were housed in plastic cages with 5 animals in each, in standard conditions (Humidity $50 \%$ $\pm 10 \%$, room temperature $20 \pm 1{ }^{\circ} \mathrm{C}$ in 12 hours night / 12 hours daytime period) without any restriction on food and water during the study. All protocols and animal care were carried out in compliance with guidelines determined by the Experimental Medicine Application and Research Center Ethics Committee (Approval no: 2008/35).

The animals were randomly separated into six groups and the animals of each group were treated as presented in the Table 1. The drug doses used in this study were based on the literature $(16,17)$.

Table 1. Study groups.

\begin{tabular}{|l|l|}
\hline Groups & Treatments \\
\hline Control-I $(\mathbf{n}=10)$ & $\begin{array}{l}1 \mathrm{ml} / \mathrm{kg} 0.9 \% \mathrm{NaCl} \text { was subcutaneously administered } \\
\text { daily for } 15 \text { days }\end{array}$ \\
\hline Control-II $(\mathbf{n}=10)$ & $\begin{array}{l}1 \mathrm{ml} / \mathrm{kg} 0.9 \% \mathrm{NaCl} \text { was subcutaneously administered } \\
\text { daily for } 30 \text { days }\end{array}$ \\
\hline CsA-I $(\mathbf{n}=10)$ & $\begin{array}{l}10 \mathrm{mg} / \mathrm{kg} \text { CsA was subcutaneously administered daily } \\
\text { for } 15 \text { days }\end{array}$ \\
\hline CsA-II $(\mathbf{n}=10)$ & $\begin{array}{l}10 \mathrm{mg} / \mathrm{kg} \text { CsA was subcutaneously administered daily } \\
\text { for } 30 \text { days }\end{array}$ \\
\hline Tac-I $(\mathbf{n}=10)$ & $\begin{array}{l}1.5 \mathrm{mg} / \mathrm{kg} \text { Tac was subcutaneously administered } \\
\text { daily for } 15 \text { days }\end{array}$ \\
\hline Tac-II $(\mathbf{n}=10)$ & $\begin{array}{l}1.5 \mathrm{mg} / \mathrm{kg} \text { Tac was subcutaneously administered } \\
\text { daily for } 30 \text { days }\end{array}$ \\
\hline
\end{tabular}

$n$ : Number, NaCl: Sodium Chloride, CSA: Cyclosporine (Sandimmune Neoral; Novartis Pharma, East Hanover, NJ, USA), Tac: Tacrolimus (Prograf; Eczacibasi Pharmaceutical Marketing Inc., Kerry, Ireland).

The weight of the rats was measured, and the dose of the drug was adjusted at the beginning of the experiment. The animals were weighed, and the doses were readjusted daily according to body weight daily. The weights were measured again at the end of the experiment, and the animals were euthanized with a pentobarbital overdose (100 $\mathrm{mg} / \mathrm{kg}$ intraperitoneal) (Nembutal;100 mg/mL,Abbott Laboratories,Chicago, IL) on the $16^{\text {th }}$ and $31^{\text {st }}$ days. Histological and histomorphometric analyses were performed.

\subsection{Histological Procedures}

The right mandibular segment of each animal was dissected from the surrounding soft tissues and fixed in buffered formal saline ( $0.1 \mathrm{M}, \mathrm{pH} 7.4$ ) for 48 hours. Then, the samples were decalcified in $10 \%$ ethylene diamine tetra acetic acid (EDTA;Titriplex,Merck Darmstadt,Germany) for 3 months at $4{ }^{\circ} \mathrm{C}$. The decalcification of the samples was confirmed radiographically.

The decalcified tissue samples were processed by routine histological procedures and immersed in paraffin blocks as described below. After decalcification was completed, the samples were washed overnight under running water, the samples were then transferred to the tissue monitoring device and were passed once through $80^{\circ}$ and $90^{\circ}$ alcohols, three times through $96^{\circ}$ alcohols; three times through isopropyl alcohol; twice through xylol and twice through 
hot paraffin respectively and subsequently blocked. The blocks were sectioned transversally through the first molar teeth level with rotary microtome (SM 2000R;Leica microsystems, Heidelberg,Germany). From each tissue sample, 6 tissue sections at $6 \mu \mathrm{m}$ thick were taken on polyL-lysine coated glass slides and dried overnight in the oven at $37^{\circ} \mathrm{C}$. Tissue sections were rehydrated by deparaffinization in the xylene series followed by a reduced concentration of ethyl alcohol and then transferred to deionized distilled water. Three of the sections from each tissue sample were stained with Crossmon's three chrome stain (18). The specimens were covered with cover glass using synthetic resin.

\subsection{Histomorphometric Analysis}

All specimens were evaluated under a light microscope (Nikon Eclipse E400;Nikon,Tokyo,Japan) with digital imaging system. Selected microscopic images were recorded and processed using image-analyzing software (BS 200 PRO;BAB Image Analyzing Systems, Ankara, Turkey). Histomorphometric analysis was performed to quantify the amounts of the tissue types mentioned above by an examiner who was blind to the experimental design (i.ç.). In these specimens, the following linear measurements of the gingiva were determined by the modification of the histomorphometric methods described previously (Figure 1) $(19,20)$ :

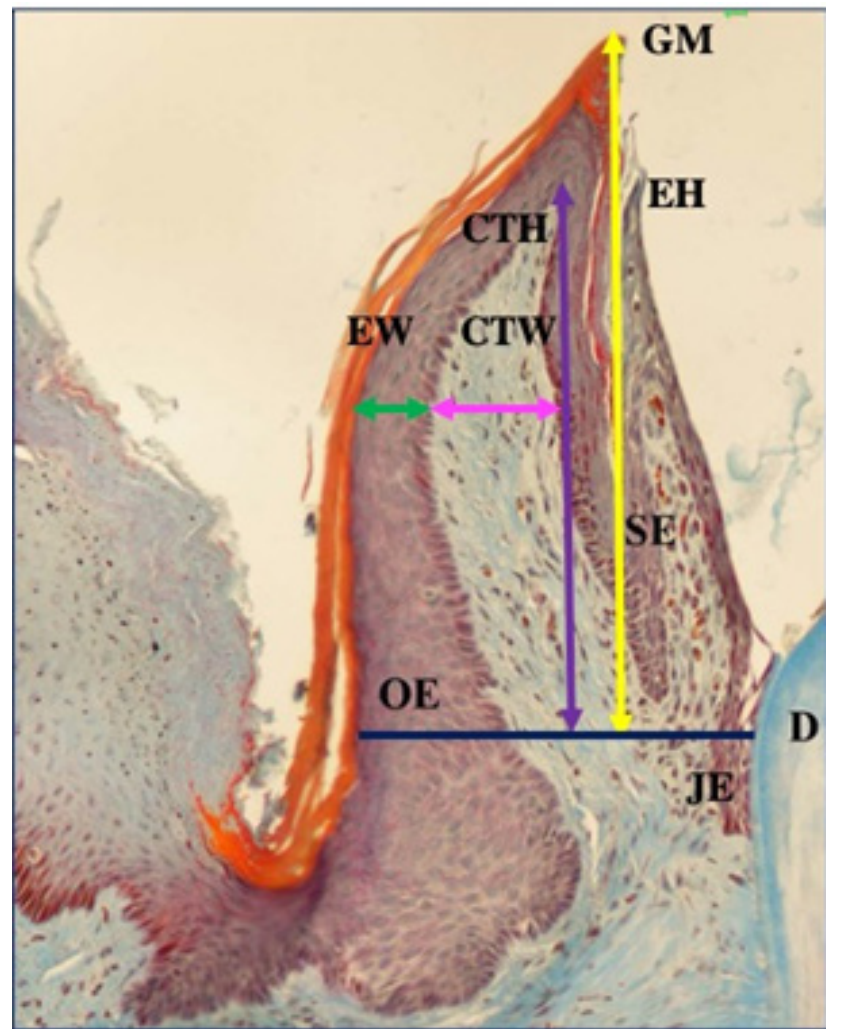

Figure 1. Measurements on the buccal gingiva of right mandibular molars (Crossmon's three chrome stain). GM: Gingival Margin, EH: Oral Epithelium Height (Yellow arrow), EW: Oral Epithelium Width (Green arrow), CTH: Connective Tissue Height (Purple arrow), CTW: Connective Tissue Width (Pink arrow), OE: Oral Epithelium, SE: Sulcular Epithelium, JE: Junctional Epithelium, D: Dentin.
Oral Epithelium Height (EH): The distance between the gingival margin and the most coronal cell of the junctional epithelium.

Oral Epithelium Width (EW): The distance between the outer epithelial surface and oral epithelium-connective tissue interface; measured at the coronal, middle and apical part of the free gingiva, with average of these measurements then calculated.

Connective Tissue Height (CTH): The distance between the most coronal point of the connective tissue and the most coronal cell of the junctional epithelium.

Connective Tissue Width (CTW): The distance between the oral epithelium-connective tissue interface and sulcular epithelium - connective tissue interface; measured at the coronal, middle and apical part of the connective tissue, with the average of these measurements then calculated.

\subsection{TRAP Histochemistry}

In the remaining 3 sections of each tissue sample, TRAP staining was performed by the method described previously (21). Briefly, the sections were deparaffinized, rehydrated and incubated in incubating solution $(\mathrm{pH} \mathrm{5})$ at $37^{\circ} \mathrm{C}$ for 45 minutes. The solution contained naphthol AS-BI phosphate (Sigma;St. Louis, MO, USA) dissolved in an acetate buffer (0.2M, pH 5) as a substrate, $50 \mathrm{mM}$ tartaric acid (Sigma;St. Louis, MO, USA) as an acid phosphatase blocking agent and fast-Red Violet LB diazonium salt (Sigma;St. Louis, MO, USA) as a chromogen. At the end of the TRAP reaction, the sections were stained with $1 \%$ methyl green prepared in $0.2 \mathrm{M}$ acetate buffer ( $\mathrm{pH}$ 5.2) for cell nuclei. The specimens were covered with cover glass by using Kaiser's gelatin. TRAPpositive areas were determined by a digital image analysis system (BS 200 PRO;BAB Image Analyzing Systems, Ankara, Turkey). From the data obtained, the TRAP-positive area ratio (TRAP-positive area/total image area X $100=$ TRAP-positive area percentage in total image area) was calculated in the unit tissue area $\left(1.23 \times 10^{8} \mu \mathrm{m}^{2}\right)$. TRAP-positive regions in 10 different areas of each specimen were determined in a unit tissue area and expressed as a percentage (\%) of the unit area.

\subsection{Statistical Analysis}

The sample size calculated by $\mathrm{R}$ program (version 3.6.2) was 10 animals per group (power $=80 \%$ ). A statistical analysis using package program (SPSS Inc.,Chicago, IL, USA) version 17 software was performed for the statistical analysis of the obtained numerical data. The data showed normal distribution; differences within and between the groups were compared by one-way analysis of variance (ANOVA) and CSA-I and CsA-II groups were compared by dependent two samples t-test. The significance level was $\alpha=0.05$. 


\section{RESULTS}

\subsection{Clinical Findings}

Any unexpected clinical and systemic changes attributable to CsA and Tac were not observed in any of the animals during the experiment. All CsA-administered rats presented GO after 15 and 30 days of treatment. There were no significant differences $(P>0.05)$ in the body weight between the groups at the baseline and the $16^{\text {th }}$ day of the experiment (Table 2). However, at the $31^{\text {st }}$ day of the study, the mean body weight of the CsA - administered group was significantly $(P<0.05)$ lower than those of the other groups.

Table 2. The mean body weights $(g)$ of the groups.

\begin{tabular}{|c|c|c|c|}
\hline & Control & CsA & Tac \\
\hline $\begin{array}{l}\text { Baseline } \\
\text { (Mean士SD) }\end{array}$ & $\begin{array}{c}196.23 \pm 17.04 \\
(n=20)\end{array}$ & $\begin{array}{c}194.75 \pm 14.04 \\
(n=20)\end{array}$ & $\begin{array}{c}202.93 \pm 12.88 \\
(n=20)\end{array}$ \\
\hline $\begin{array}{l}16^{\text {th }} \text { day } \\
\text { (Mean } \pm S D)\end{array}$ & $\begin{array}{c}193.93 \pm 30.22 \\
(n=10)\end{array}$ & $\begin{array}{c}206.62 \pm 13.57 \\
(n=10)\end{array}$ & $\begin{array}{c}193.32 \pm 15.46 \\
(n=10)\end{array}$ \\
\hline $\begin{array}{l}31^{\text {st }} \text { day } \\
\text { (Mean } \pm S D)\end{array}$ & $\begin{array}{c}201.38 \pm 12.28 \\
(n=10)\end{array}$ & $\begin{array}{c}161.36 \pm 14.44^{*,+}+ \\
(n=10)\end{array}$ & $\begin{array}{c}201.30 \pm 20.49 \\
(n=10)\end{array}$ \\
\hline
\end{tabular}

n: Number, CSA: Cyclosporine, Tac: Tacrolimus, SD: Standart Deviation.

"Significantly different from the control group $(P<0.05)$.

${ }^{+}$Significantly different from the Tac group $(P<0.05)$.

$P<0.05$ was considered statistically significant.

\subsection{Histological and Histomorphometrical Findings}

In all specimens, enamel was completely decalcified and disappeared; thus, a definite enamel space was seen. Severe epithelial hyperplasia with mononuclear cell infiltration was observed in both CsA-I and CsA-II groups. Vascularization was also highly developed in the connective tissue. In some of the specimens, erosion and detachment of both JE and SE were seen, and the gingival sulcus was filled with bacterial plaque (Figure 2A-2B).
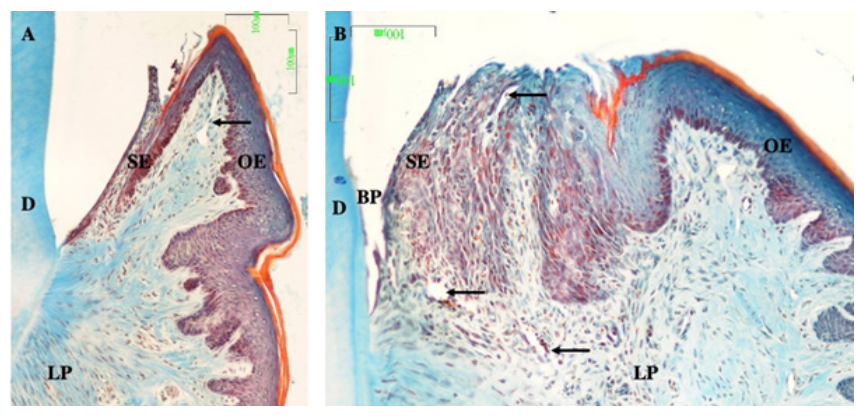

Figure 2. Sections from the buccal gingiva (Crossmon's three chrome stain). (A) CSA-I group. (B) CSA-II group. OE: Oral Epithelium, SE: Sulcular Epithelium, LP: Lamina Propria, D: Dentin, BP: Bacterial Plaque, Black Arrows: Vascularization.

Structural changes in both the epithelium and connective tissues of the Tac-I and Tac-II groups were generally quite mild. Mild mononuclear cell infiltration with increased vascularity in both epithelium and lamina propria was observed. Bacterial plaque in the gingival sulcus was seen (Figure 3A-3B).
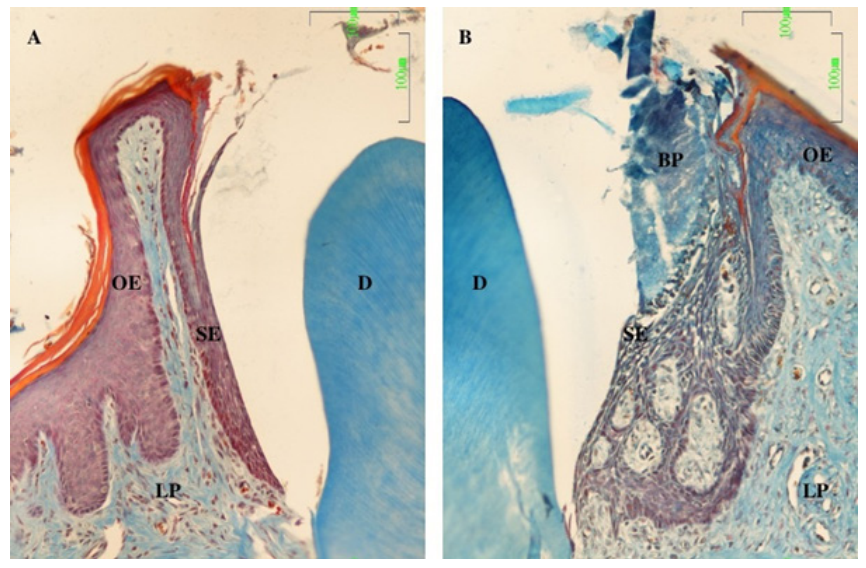

Figure 3. Sections from the buccal gingiva (Crossmon's three chrome stain). (A) Tac-I group. (B) Tac-II group. OE: Oral Epithelium, SE: Sulcular Epithelium, LP: Lamina Propria, D: Dentin, BP: Bacterial Plaque.

Oral epithelium (OE), sulcular epithelium (SE) and junctional epithelium (JE) were normal in structure in both Control-I and Control-II groups. Mild mononuclear cell infiltration in the lamina propria (LP) was seen. Any detachment in JE, cellular debris and epithelial erosion was not observed. There were no apparent histological differences between Control-I and Control-II groups (Figure 4A-4B).
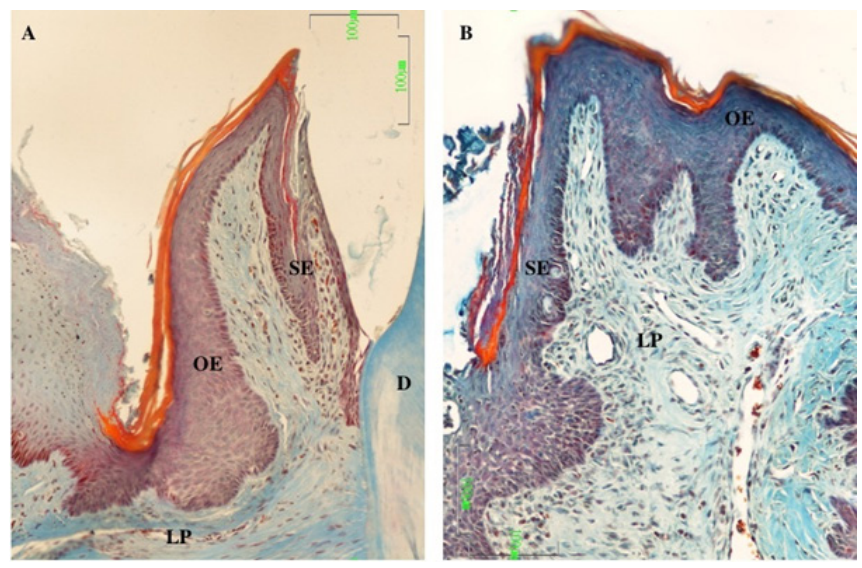

Figure 4. Sections from the buccal gingiva (Crossmon's three chrome stain). (A) Control-I group. (B) Control-II group.OE: Oral Epithelium, SE: Sulcular Epithelium, LP: Lamina Propria, D: Dentin.

\subsection{Gingival Histomorphometry}

The histomorphometric measurements of the gingiva confirmed the histological findings. Table 3 indicates the histomorphometric measurements of the gingiva on the $16^{\text {th }}$ and $31^{\text {st }}$ days.

The 16-day EH, EW, and CTW values in the CsA group were significantly higher than the other groups $(P<0.05)$. However, no significant difference was observed between the groups when the 16-day CTH value was examined $(P>0.05)$. The Tac-I group had similar EH, EW, CTH, and CTW values to those of the Control-I group at the $16^{\text {th }}$ day of the experiment $(P>0.05)$. 
Table 3. Histomorphometric measurements of the gingiva on the $16^{\text {th }}$ day and on the $31^{\text {st }}$ day.

\begin{tabular}{|c|c|c|c|c|c|c|c|}
\hline \multicolumn{4}{|l|}{$16^{\text {th }}$ day } & \multicolumn{4}{|l|}{$31^{\text {st }}$ day } \\
\hline $\begin{array}{l}\text { Measurements } \\
(\mathrm{mm})\end{array}$ & $\begin{array}{l}\text { Control-I } \\
(n=10)\end{array}$ & $\begin{array}{l}\text { CsA-I } \\
(n=10)\end{array}$ & $\begin{array}{l}\text { Tac-I } \\
(n=10)\end{array}$ & $\begin{array}{l}\text { Measurements } \\
(\mathrm{mm})\end{array}$ & $\begin{array}{l}\text { Control-II } \\
(n=10)\end{array}$ & $\begin{array}{l}\text { CsA-II } \\
(n=10)\end{array}$ & $\begin{array}{l}\text { Tac-II } \\
(n=10)\end{array}$ \\
\hline $\begin{array}{l}\text { EH } \\
\text { (Mean士SD) }\end{array}$ & $56.45 \pm 0.65$ & $59.26 \pm 2.19^{*},+$ & $56.92 \pm 0.85$ & $\begin{array}{l}\text { EH } \\
\text { (Mean士SD) }\end{array}$ & $56.74 \pm 0.36$ & $125.82 \pm 10.31^{\ddagger, \S, \|}$ & $58.61 \pm 1.20$ \\
\hline $\begin{array}{l}\text { EW } \\
\text { (Mean士SD) }\end{array}$ & $49.66 \pm 1.30$ & $53.99 \pm 1.80^{*},+$ & $49.92 \pm 1.17$ & $\begin{array}{l}\text { EW } \\
\text { (Mean士SD) }\end{array}$ & $49.77 \pm 0.84$ & $114.96 \pm 2.77^{\ddagger, \S, । I}$ & $49.97 \pm 1.05$ \\
\hline $\begin{array}{l}\text { CTH } \\
\text { (Mean士SD) }\end{array}$ & $307.88 \pm 1.56$ & $311.49 \pm 5.75$ & $307.96 \pm 2.52$ & $\begin{array}{l}\text { CTH } \\
\text { (Mean士SD) }\end{array}$ & $307.98 \pm 3.02$ & $640.13 \pm 6.88^{\ddagger, \S, \|}$ & $308.62 \pm 2.82$ \\
\hline 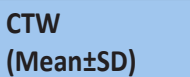 & $94.61 \pm 0.77$ & $100.03 \pm 3.41^{*},+$ & $94.86 \pm 2.60$ & 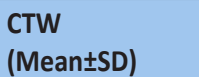 & $94.84 \pm 1.60$ & $204.91 \pm 16.73^{\ddagger, \S, \| ।}$ & $98.36 \pm 2.90$ \\
\hline
\end{tabular}

n: Number, CSA: Cyclosporine, Tac: Tacrolimus, SD: Standart Deviation, EH: Oral Epithelium Height, EW: Oral Epithelium Width, CTH: Connective Tissue Height, CTW: Connective Tissue Width. ${ }^{*}$ Significantly different from the Control-I group $(P<0.05){ }^{+}{ }^{+}$Significantly different from the Tac-I group (P<0.05).

${ }^{\ddagger}$ Significantly different from the Control-II group (P<0.05); § Significantly different from the Tac-II group (P<0.05).; " Significantly different from the CsA-I group $(P<0.05) ; " ⿱ P<0.05$ was considered statistically significant.

The 31-day EH, EW, CTH, and CTW values in the CSA group were significantly higher than in the other groups $(P<0.05)$. The Tac-II group had similar EH, EW, CTH, and CTW values to those of the Control-II group at the $31^{\text {st }}$ day of the experiment $(P>0.05)$. However, there were similar linear measurements in all dimensions in the Tac and Control groups at all periods of the experiment $(P>0.05)$.

\subsection{TRAP Histochemistry}

TRAP-positivity was observed as a dark red reaction product in the cytoplasm of osteoclasts located on the surface of the bone trabeculae (Figure $5 \mathrm{~A}-\mathrm{C}$ ). This reaction product was not found in the other cells of the bone tissue and the connective tissue. In the CsA treated groups, alveolar bone trabeculae were relatively narrower than in the other groups.

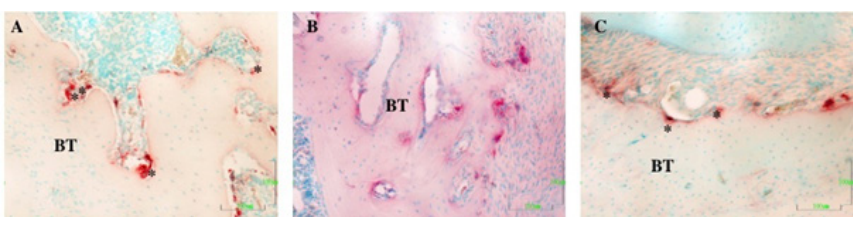

Figure 5. Sections from the alveolar bone. (A) CSA-II group. (B) Tac-II group. (C) Control-ll group.

BT: Bone Trabecula, *: TRAP positive osteoclastic cells on the trabecula.

The 16-day and 31-day TRAP-positivity values of the groups are shown in Table 4. No significant difference was found between the 16-day TRAP-positivity values of the groups $(P=0.05)$. However, on the $31^{\text {st }}$ day, the TRAP-positivity values of the CsA group were significantly higher than those of the other groups $(P<0.05)$. No significant difference was found between 16 and 31 days in the Tac and the control groups in terms of TRAP-positivity $(P>0.05)$. Although TRAPpositivity values in the CsA group at 31 days were higher than those of the 16 days, no significant difference was found $(P=0.05)$.
Table 4. The mean percentage (\%) of TRAP-positivity.

\begin{tabular}{|l|l|l|l|}
\hline & $\begin{array}{l}\text { Control-I } \\
(\mathbf{n}=10)\end{array}$ & $\begin{array}{l}\text { CsA-I } \\
(\mathbf{n}=10)\end{array}$ & $\begin{array}{l}\text { Tac-I } \\
(\mathbf{n}=10)\end{array}$ \\
\hline $16^{\text {th }}$ day (Mean $\left.\pm S D\right)$ & $0.27 \pm 0.08$ & $0.44 \pm 0.24$ & $0.26 \pm 0.08$ \\
\hline & $\begin{array}{l}\text { Control-II } \\
(\mathbf{n}=10)\end{array}$ & $\begin{array}{l}\text { CsA-II } \\
(\mathbf{n}=10)\end{array}$ & $\begin{array}{l}\text { Tac-II } \\
(\mathbf{n}=10)\end{array}$ \\
\hline $31^{\text {st }}$ day (Mean $\left.\pm S D\right)$ & $0.26 \pm 0.07$ & $0.66 \pm 0.15^{*},+$ & $0.26 \pm 0.08$ \\
\hline
\end{tabular}

TRAP: Tartrate Resistant Acid Phosphatase, n: Number, CsA: Cyclosporine, Tac: Tacrolimus, SD: Standart Deviation.

"Significantly different from the Control-II group $(P<0.05)$.

${ }^{+}$Significantly different from the Tac-Il group $(P<0.05)$.

" $P<0.05$ was considered statistically significant.

\section{DISCUSSION}

In patients using calcineurin inhibitors as immunosuppressive agents to prevent organ transplant rejection, the occurrence of osteopenia has been reported as a common complication (2). However, in these patients, osteopenia has frequently been attributed to the use of glucocorticoids, which often accompany the treatment regimen (22). On the other hand, the results of very few studies using calcineurin inhibitors alone without the use of glucocorticoids are contradictory and the effects on the alveolar bone of both drugs are still unclear $(11,14)$, although Tac has been shown to cause GO less frequently or less severely than CsA (8). Therefore, the purpose of our study is to reveal and to compare the effects of both drugs on the gingiva and alveolar bone. Moreover, revealing the efficacy of these drugs, particularly on the alveolar bone, may be useful in developing new approaches in the prevention and treatment of periodontal diseases in the future.

The major problem in human studies regarding the mechanism of action of immunosuppressants is the inhomogeneity of variables such as genetic predisposition, transplanted organs, age, duration and dose of treatment $(5,23)$. Since the patients taking the immunosuppressants use a number of concomitant drugs, the effect of each drug individually may not be fully revealed. In our study, an experimental rat model was chosen to overcome these difficulties. Furthermore, quantitative histological evaluations have been 
shown to be among the best methods of showing the effect of drugs on tissue (24). Our study presents novelty with the histopathological evaluation of TRAP levels. Although there are animal studies evaluating the effects of both CsA and Tac on the alveolar bone, TRAP levels were evaluated in serum but no histopathological evaluation was made $(12,13,23)$.

CsA and Tac have been administered by different methods when using drug-induced GO models in animals. It has been reported that different degrees of absorption occur in perioral administration and the serum level of the drug administered perorally is not sufficient to provide immunosuppression (25). In intraperitoneal administration, CsA has been shown to have negative side effects associated with high concentrations (25). Subcutaneous administration in male rats was chosen in our study in order to obtain a more consistent cycle. The risk and severity of drug-related GO tend to be higher in men (26). In an animal study (26), male rats were found to be more prone to nifedipine-related GO than were females. Although the serum levels of the drugs used in the present study were not measured, the doses of both drugs have previously been shown to provide sufficient and constant levels in serum to produce immunosuppression in rats $(16,17,25)$.

In the present study, GO was prominent on the $16^{\text {th }}$ and $31^{\text {st }}$ days following the subcutaneous administration of CsA $10 \mathrm{mg} / \mathrm{kg} /$ day. GO related to CsA is a well-established phenomenon in the literature $(9,27,28)$. In our study, gingival measurements in all dimensions were greater in the groups administered CsA compared to the other groups, and this finding is in accordance with previous studies $(5,13,29)$.

There is limited information in the literature about the effect of Tac on GO. Costa et al. (9) reported lower prevalence and severity of GO for Tac than CsA and other authors suggested that Tac did not cause GO $(5,13,29)$. In accordance with these studies, the groups administered Tac did not develop statistically significant GO in our study. In addition, the gingival parameters measured in the Tac groups were quite similar to those in the control group on both the $16^{\text {th }}$ and $31^{\text {st }}$ days $(P>0.05)$. Nassar et al. (30) reported that Tac did not cause GO over 120 days of drug use, whereas Tac-induced GO started from the $180^{\text {th }}$ day and continued through to the $240^{\text {th }}$ day of the experiment. They suggested that Tacinduced GO in rats may be time-related. This report supports our findings that Tac has no GO effect in short term use. In the study of Prabhu et al (4), which has a similar design to our study, the GO in the Tac group in rats on the $16^{\text {th }}$ and $31^{\text {st }}$ days was lower than that of the CsA group, in accordance with our study. However, the dose of CsA administered in their study was $30 \mathrm{mg} / \mathrm{kg} /$ day and both drugs were given to the rats via gavage.

In accordance with previous studies, in our study CsA caused a significant increase in TRAP positivity, which is a bone resorption parameter. However, in our study, Tac had no significant effect on TRAP. Consistent with the results of our study, in the study of Spolidorio et al. (13), in addition to marked gingival growth due to CsA on the $60^{\text {th }}$ and $120^{\text {th }}$ days, bone resorption, serum TRAP levels and the osteoclast count were significantly higher than in the other groups. In our study, TRAP-positivity was found to be significantly higher in the CsA-treated group than in the control and Tac groups. In both studies, no difference was found between the Tac and control groups in terms of TRAP levels. These results show that Tac does not cause significant bone resorption. However, it should be emphasized that studies examining the impact of Tac on bone metabolism are still contradictory. In other studies that showed an increase in serum TRAP levels, it has been found that Tac increases bone resorption and causes osteopenia $(12,23)$. The variety of parameters such as the age and weight of the animals, the nature of the bone, the method of evaluation, the duration and dose of the drug in these studies seems to give rise to different results.

The findings of this study have to be seen in light of some limitations. One of the study's limitation is the small sample size of the rats. Though the sample size meets the adequacy criterion, authors believe that taking a large sample in each group might have improved the results of the study as well as the generalizability of the study. The data from our study should be used to design larger confirmatory studies. The second limitation of our study is the difficulty in adapting the results of our study, which is an animal experiment model, to clinical applications in humans. We should be careful in interpreting and drawing conclusions based on data obtained from animals due to genetic and environmental divergence. The last limitation of our study is the lack of the long-term drug-administered groups. The effects of both calcineurin inhibitors on GO and bone metabolism depend on the dose and duration of administration. Further studies are needed in order to understand the effects of CsA and Tac on GO and bone metabolism.

\section{CONCLUSION}

In conclusion, within the limitations of our study, Tac does not cause GO and alveolar bone resorption. Using Tac for a longer period of time may cause gingival overgrowth, which reveals the importance of the duration of the treatment in terms of its side effects. We suggest that Tac may be an alternative to CsA to prevent gingival overgrowth and alveolar bone destruction, given the side effects of CsA.

\section{Acknowledgements}

This study was supported by Selcuk University Scientific Research Projects Coordinatorship (Konya, Turkey) with project number 09202006.

\section{REFERENCES}

[1] Dongari-Bagtzolou A, Cutler C. Drug-associated gingival enlargement. J Periodontol 2004; 75:1424-1431.

[2] Mihatsch MJ, Kyo M, Morozumi K, Yamaguchi Y, Nickeleit V, Ryffel B. The side-effects of cyclosporine-A and tacrolimus. Clin Nephrol 1998 Jun; 49(6):356-363. 
[3] Spencer CM, Goa KL, Gillis JC. Tacrolimus. An update of its pharmacology and clinical efficacy in the management of organ transplantation. Drugs 1997 Dec; 54(6):925-975.

[4] Prabhu A, Mehta DS. A morphologic comparison of gingival changes influenced by cyclosporin and tacrolimus in rats: An experimental study. J Periodontol 2006; 77(2):265-270.

[5] Spolidorio LC, Holzhausen M, Spolidorio DMP, Nassar CA, Nassar PO, Muscará MN. Cyclosporin but not tacrolimus significantly increases salivary cytokine contents in rats. J Periodontol 2005; 76(9):1520-1525.

[6] Martins L, Ventura A, Branco A, Carvalho MJ, Henriques AC, Dias L, Sarmento AM, Amil M. Cyclosporine versus tacrolimus in kidney transplantation: Are there differences in nephrotoxicity? Transplant Proc 2004 May; 36(4):877-879.

[7] James JA, Jamal S, Hull PS, Macfarlane T V, Campbell BA, Johnson RWG, Short CD. Tacrolimus is not associated with gingival overgrowth in renal transplant patients. J Clin Periodontol 2001; 28(9):848-852.

[8] Lima RB, Benini V, Sens YAS. Gingival overgrowth in renal transplant recipients: a study concerning prevalence, severity, periodontal, and predisposing factors. Transplant Proc 2008 Jun; 40(5):1425-1428.

[9] de Oliveira Costa F, Diniz Ferreira S, de Miranda Cota LO, da Costa JE, Aguiar MA. Prevalence, severity, and risk variables associated with gingival overgrowth in renal transplant subjects treated under tacrolimus or cyclosporin regimens. J Periodontol 2006; 77(6):969-975.

[10] Bader G, Lejeune S, Messner M. Reduction of cyclosporineInduced gingival overgrowth following a change to tacrolimus. A case history ınvolving a liver transplant patient. J Periodontol 1998; 69(6):729-732.

[11] Andia DC, Nassar CA, Nassar PO, Guimarães MR, Cerri PS, Spolidorio LC. Treatment with tacrolimus enhances alveolar bone formation and decreases osteoclast number in the maxillae: A histomorphometric and ultrastructural study in rats. Histol Histopathol 2008; 23(10):1177-1184.

[12] Kanda J, Izumo N, Furukawa M, Shimakura T, Yamamoto $\mathrm{N}$, Takahashi HE, Asakura T, Wakabayashi H. Effects of the calcineurin inhibitors cyclosporine and tacrolimus on bone metabolism in rats. Biomed Res 2018; 39(3):131-139.

[13] Spolidorio LC, Nassar PO, Nassar CA, Spolidorio DMP, Muscará $\mathrm{MN}$. Conversion of immunosuppressive monotherapy from cyclosporin A to tacrolimus reverses bone loss in rats. Calcif Tissue Int 2007; 81(2):114-123.

[14] Guimarães MR, Nassar PO, Andia DC, Nassar CA, Spolidorio DMP, Rossa C, Spolidorio LC. Protective effects of tacrolimus, a calcineurin inhibitor, in experimental periodontitis in rats. Arch Oral Biol 2007; 52(9):882-888.

[15] Karaduman B, Uraz A, Altan GNN, Tuncer BBB, Alkan Ö, Gönen $S$, Pehlivan S, Çetiner D. Changes of tumor necrosis factor- $\alpha$ interleukin-10, and tartrate-resistant acid phosphatase $5 \mathrm{~b}$ in the crevicular fluid in relation to orthodontic movement. Eur J Inflamm 2015; 13(1):3-13.

[16] Sevc J, Goldberg D, van Gorp S, Leerink M, Juhas S, Juhasova J, Marsala S, Hruska-Plochan M, Hefferan MP, Motlik J, Rypacek F, Machova L, Kakinohana O, Santucci C, Johe K, Lukacova N, Yamada K, Bui JD, Marsala M. Effective long-term immunosuppression in rats by subcutaneously implanted sustained-release tacrolimus pellet: Effect on spinally grafted human neural precursor survival. Exp Neurol 2013; 248:85-99.

[17] Wassef R, Cohen Z, Langer B. Pharmacokinetic profiles of cyclosporine in rats: Influence of route of administration and dosage. Transplantation 1985; 40(5):489-493.

[18] Culling CFA, Allison RT, Barr W. Cellular pathology technique. 4th ed. Cambridge: Elsevier Science; 2014.

[19] Berglundh T, Lindhe J, Sterrett JD. Clinical and structural characteristics of periodontal tissues in young and old dogs. J Clin Periodontol 1991; 18(8):616-623.

[20] Fischer RG, Klinge B. Clinical and histological evaluation of ligature-induced periodontal breakdown in domestic ferrets immunosuppressed by Cyclosporin-A. J Clin Periodontol 1994; 21(4):240-249.

[21] Cole AA, Walters LM. Tartrate-resistant acid phosphatase in bone and cartilage following decalcification and coldembedding in plastic. J Histochem Cytochem 1987; 35(2):203206.

[22] Martín-Fernández M, Rubert M, Montero $M$, de la Piedra C. Effects of cyclosporine, tacrolimus, and rapamycin on osteoblasts. Transplant Proc 2017; 49(9):2219-2224.

[23] Rubert M, Montero M, Guede D, Caeiro JR, Martín-Fernández M, Díaz-Curiel M, de la Piedra C. Sirolimus and tacrolimus rather than cyclosporine $A$ cause bone loss in healthy adult male rats. Bone Reports 2015; 2:74-81.

[24] Dos Santos RL, Pithon MM, Lacerda MCM, Ruellas ACDO, Maia LC. Does the use of tacrolimus influence alveolar bone metabolism? Vol. 10, International Journal of Endocrinology and Metabolism 2012; 429-434.

[25] Duarte PM, Nogueira Filho GR, Sallum EA, Toledo S de, Sallum AW, Nociti FH. The effect of an Immunosuppressive therapy and its withdrawal on bone healing around titanium Implants. A histometric study in rabbits. J Periodontol 2001; 72(10):1391-1397.

[26] Ishida $H$, Kondoh T, Kataoka M, Nishikawa S, Nakagawa T, Morisaki I, Kido J, Oka T, Nagata T. Factors Influencing Nifedipine-Induced Gingival Overgrowth in Rats. J Periodontol 1995; 66(5):345-350.

[27] Rapone B, Ferrara E, Santacroce L, Cesarano F, Arazzi M, Di Liberato L, Scacco S, Grassi R, Grassi FR, Gnoni A, Nardi GM. Periodontal microbiological status influences the occurrence of cyclosporine-a and tacrolimus-induced gingival overgrowth. Antibiotics 2019; 8(3).

[28] Paixão CG, Sekiguchi RT, Saraiva L, Pannuti CM, Silva HT, Medina-Pestana JO, Romito GA. Gingival overgrowth among patients medicated with cyclosporin a and tacrolimus undergoing renal transplantation: a prospective study. J Periodontol 2011; 82(2):251-258.

[29] Pamuk F, Cetinkaya BO, Ayas B, Keles GC, Gacar A. Evaluation of gingival alterations in rats medicated with cyclosporine $A$, tacrolimus and sirolimus: A stereological study. J Periodontal Res 2015; 50(5):629-636.

[30] Nassar CA, Nassar PO, Andia DC, Guimarães MR, Spolidorio LC. The effects of up to 240 days of tacrolimus therapy on the gingival tissues of rats - A morphological evaluation. Oral Dis 2008; 14(1):67-72.

How to cite this article: Karaduman U, Karaduman B, Celik I, Gursel M. The Effects of Cyclosporine and Tacrolimus on Gingiva and Alveolar Bone of Rats. Clin Exp Health Sci 2021; 11: 516-522. DOI: 10.33808/clinexphealthsci.835833 